DOI:10.26080/krrmkozl.2013.2.125

\title{
Régészeti ásatás és falkutatás a siroki várban (2010-2012)
}

\author{
FÜLÖP ANDRÁS - HÉCZEY-MARKÓ ÁGNES \\ Magyar Nemzeti Múzeum - Nemzeti Örökségvédelmi Központ \\ H-1113 Budapest, Daróczi út 3., \\ andras.fulop@mnm-nok.gov.hu, agnes.marko@mnm-nok.gov.hu
}

Fülöp, A. - Héczey-Markó, Á.: Archeological investigations in the castle of Sirok (2010-2012)

Abstract: In this article the authors present the latest excavation, which was carried on in the western part of the upper castle of Sirok. The lower fortress was reconstructed for tourism financed by the European Union. The remnants of the embrasures and other objects in the bastions and other walls were documented before the building works.

Keywords: castle, building archeology, middle ages, Ottomans

\section{Bevezetés}

A siroki várban, a korábban már feltárt alsóvár turisztikai célú kiépítését célzó projekthez kapcsolódóan, 2010-2012. között falkutatást és régészeti szakfelügyeletet végeztünk. Emellett - előkészítendő a további helyreállítást - került sor az alsóvárból a felsővárba vezető, sziklába vágott lépcső érkező terének megelőző régészeti feltárására 2011. november 2. és 16. között. A régészeti munkákat a Heves Megyei Múzeumi Szervezet alvállalkozójaként a Magyar Nemzeti Múzeum, Nemzeti Örökségvédelmi Központ Műemléki Kutatási Osztálya végezte ${ }^{1}$ (1. kép).

A vár régészeti feltárását 1965-72. között Kovács Béla kezdte meg. ${ }^{2}$ Ekkor a sziklába vágott földalatti járatok és a várat körülvevő sáncárok egy részének kitisztítása mellett az alsóvár teljes belső területének, és az oda vezető kapuk előterének feltárására került sor. A kutatást 2003-ban Fülöp András folytatta, az alsóvárat északról övező plató és a felsővár szondázó kutatásával. Ugyanekkor az alsóvári sziklába vágott gyalogkapu és a 16. századi kapubástya felmérése is megtörtént. ${ }^{3}$

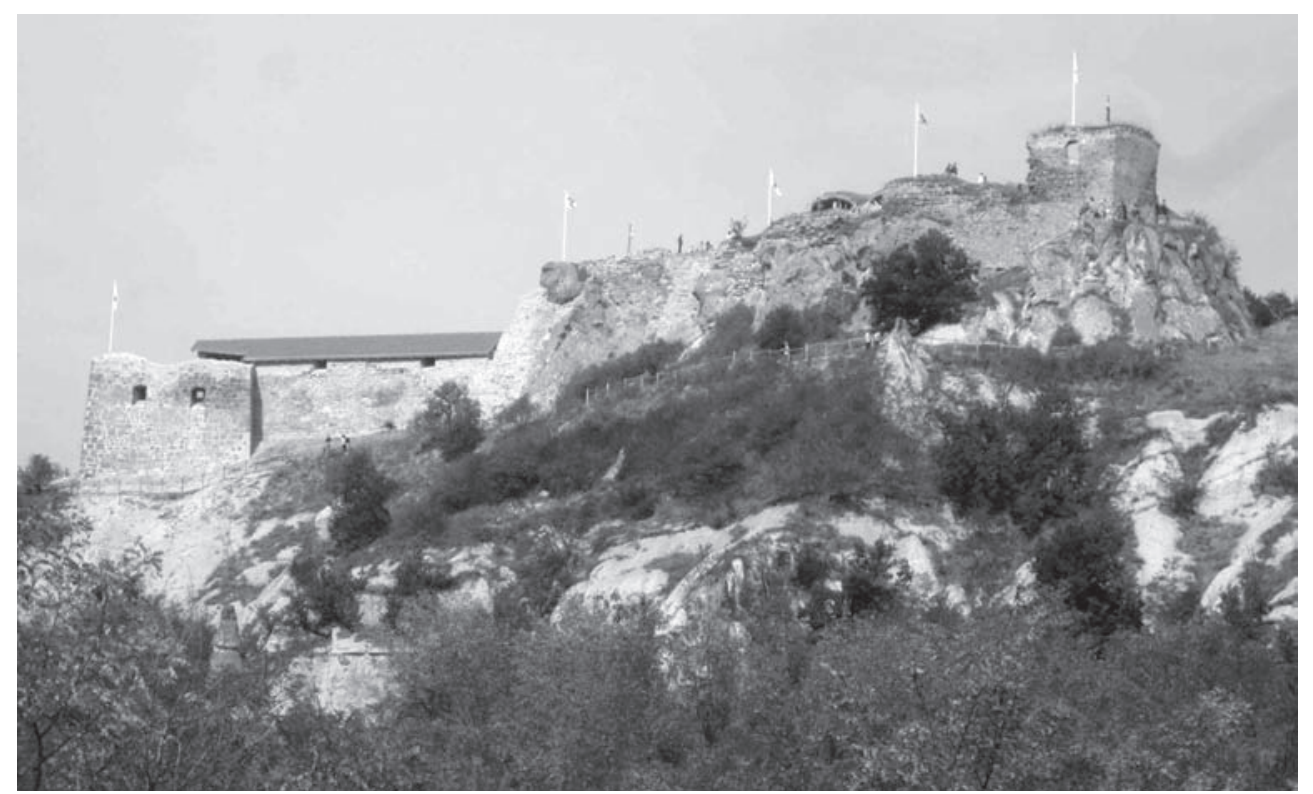

1. kép: A vár látképe délkelet felöl, helyreállítás után

1 Itt köszönjük meg Jankovics Norbert és Rácz Miklós régészeknek, továbbá Birkás Péter, Bodródi Miklós, Bősz Attila, Simó Attila, Szabó Zoltán, Zsubori István régésztechnikusoknak a helyszíni munkában nyújtott segítséget.

2 A vár leírása a kutatás előtt: Gerő 1955. 199-203. Az ásatási eredményekre vonatkozó összefoglalások: Kovács 1975. 250254., Kovács 1978. 555-558.

3 Fülöp 2004

ISSN 2064-1966 (Print); ISSN 2631-0376 (Online) 


\section{A vár története}

A siroki vár történetének összefoglalása a szakirodalomban már publikálásra került, ezért jelen tanulmányunkban csak rövid összefoglalását közöljük. A vár (castrum Syruk) 1320-ban tűnik fel az okleveles forrásokban, amikor első ismert birtokosaitól, az Aba nemzetségtől Csák Máté kezére átjátszott várat Drugeth Fülöp szepesi ispán és Dózsa erdélyi vajda Károly Róbert számára elfoglalták. ${ }^{4}$ 1331-től magánkézen volt, majd 1371-72-ben I. Lajos elzálogosította Domoszlói Miklós mester hevesi ispánnak és siroki várnagynak, mivel az saját költségén kijavíttatta a várat. 1389-ben Tari László kapta adományba Sirokot, mely kései leszármazottja, az örökös nélkül elhunyt Tari György rendelkezésének megfelelően, 1472-ben Országh Mihály nádorra és Kompolti Miklósra szállt. Kompolti Miklós fia János halálát (1511) követő években Országh László, ez utóbbi elhunytával pedig Országh Kristóf örökölte a várat, aki ideköltözött feleségével, Zrínyi llonával. ${ }^{5}$ Országh Kristóf nevéhez fúződik az ötszögű bástyákkal megerősített alsóvár mai formában való kiépítése. Vályi András országleírásában idézi a "külső kapu felett” akkor még látható, 1562-es feliratot: „Magnificus Dominus Cristophorus Ország de Gut Co. Neugrad, ac S. Rom. Caes. Mttis. Pincerna" ${ }^{6}{ }^{6}$ Országh Kristóf 1567. évi halála után a várat veje, enyingi Török Ferenc megváltotta a királytól, akitől Zsuzsanna leánya és annak férje, Nyáry Pál örökölte 1596-ban, Eger eleste után kardcsapás nélkül került török kézre a vár. Miután a törökök 1687 őszén, pár napos harc után, a hadifelszerelés és az élelem nagy részét hátrahagyva feladták Sirokot, a várról és felszereléséről inventárium ${ }^{7}$ készült. Ezután magyar hajdúk szálltak meg benne, majd a Rákóczi-szabdságharc idején kuruc katonák húzták meg magukat falai közt. Az ezt követő időszakban tulajdonosaik elhanyagolták a várat, ám a kőfalak még ekkor is álltak, amint arról Bél Mátyás tudósít. 1711 után a Nyáry család örökölte, majd nőági leszármazottai 1841-ben gr. Károlyi Györgynek adták el Sirokot, ami a Károlyiak birtokában maradt egészen 1945-ig.

\section{Eredmények}

A 13-14. században épült felsővár a ma látható szintviszonyok alapján három, keletről nyugatra lépcsőzetesen csökkenő magasságú platóra tagolódik. A 2003. évi kutatás a keleti részen a várfallal egykorú, kelet-nyugat irányú, alápincézett palotaszárnyat tárt fel. A pincét - talán a 16. század második felében - utólagos osztófalakkal feldarabolták. Ezzel egyidőben épülhetett a népnyelv által "mulatónak" nevezett, boltozott épület, és a felsővárba felvezető sziklába vágott járat ide vezető, oldalirányú elágazása (2. kép).

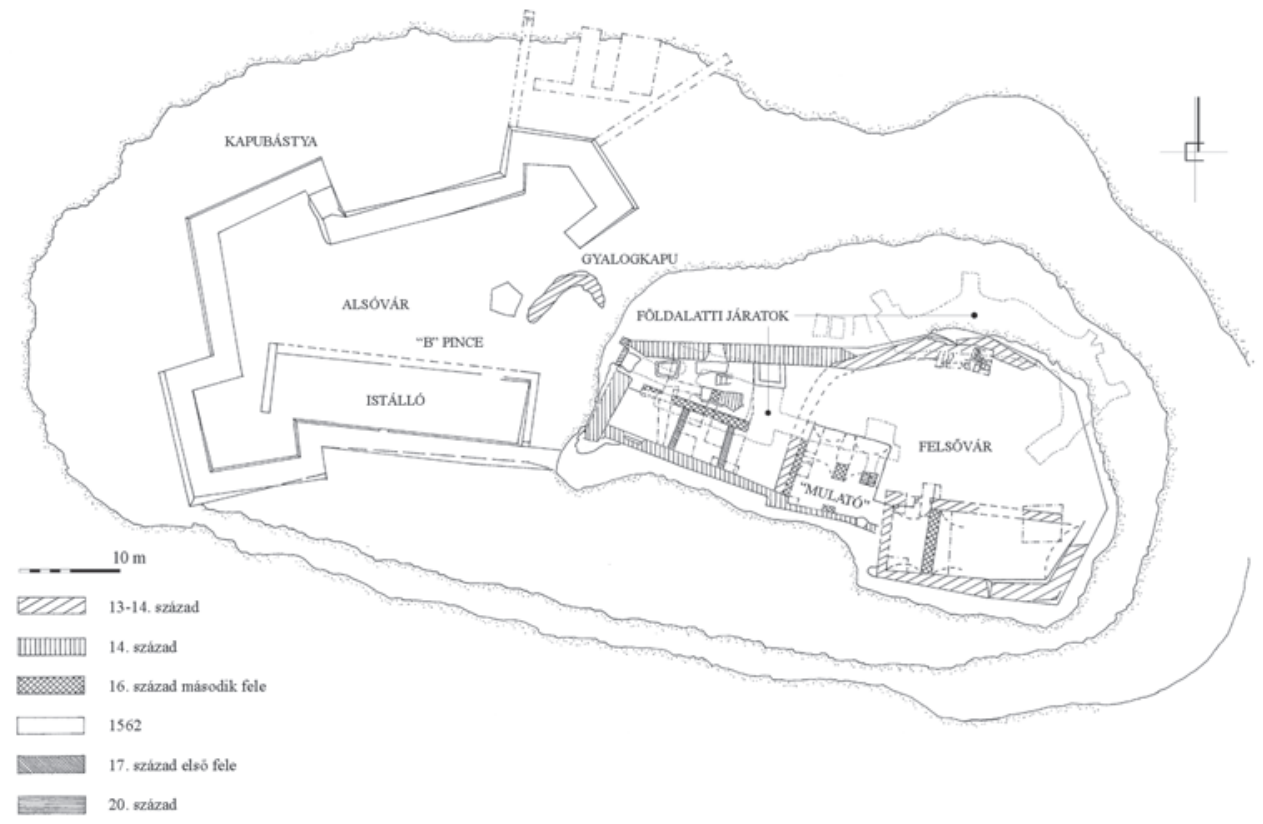

2. kép: A vár épitési periódusai

4 AO 1878. 573., AO 1881. 84-85., Zichy 1871. 219., Györffy 1987. 131.

5 Fülöp 2004. 138-140.

6 Vályi 1799. 262-263., később Rómer Flóris a felirat évszámát 1561-nek olvasta. (Kovács 1978. 556.) Rómer vonatkozó jegyzőkönyvének (XXV. köt. 100.) eredetije időközben elkallódott, így fotó sem található róla a Forster Gyula Nemzeti Örökséggazdálkodási és Szolgáltatási Központ gyűjteményében.

7 Az inventárium szövege: Fülöp 2004. 148-150. Függelék. 
A most végzett kutatás során az északi várfal középső szakaszán falelválást figyeltünk meg, melynek alapján a korábban egykorúnak feltételezett felsővár keleti részét határozhatjuk meg legkorábbiként. ${ }^{8}$ Ezen a ponton a kelet felől jövő várfal ívesen dél felé fordult. Innen nagyjából 20 méter hosszan a fal szikláig lepusztult. Fennmaradt azonban a déli várfalnak nekifutó, mintegy 1,5 méter vastag szakasza, melyhez a „mulató" nyugati fala később hozzáépült. ${ }^{9}$ A korai vármag kapuja - mivel máshol nyílás nem látható - feltehetően az alsóvárból induló, sziklába vágott lépcsős kialakítású járat (a továbbiakban sziklalépcső) felérkező nyílásával szemben, vagy attól északra, a lepusztult falszakaszon nyílt.

A jelen kutatás során feltárt terület a felsővár nyugati, legalacsonyabb szinten elhelyezkedő része, ahová az említett sziklalépcső érkezik. A feltárt területet északról, nyugatról és délről a plató szélén emelt várfalak, nyugatról pedig a felsővár korábbi, keleti részének fala határolja. Ennek mentén statikai okokból egy mintegy 3 méter széles sávot nem tudtunk feltárni. A feltárást megelőzően a területet, a sziklalépcső felérkezési helyének környezetét kivéve, gyep takarta. A teljes területet tanúfalak meghagyásával, hat ásatási szelvénnyel, sziklafelszínig mélyítve vizsgáltuk (3-4. kép).

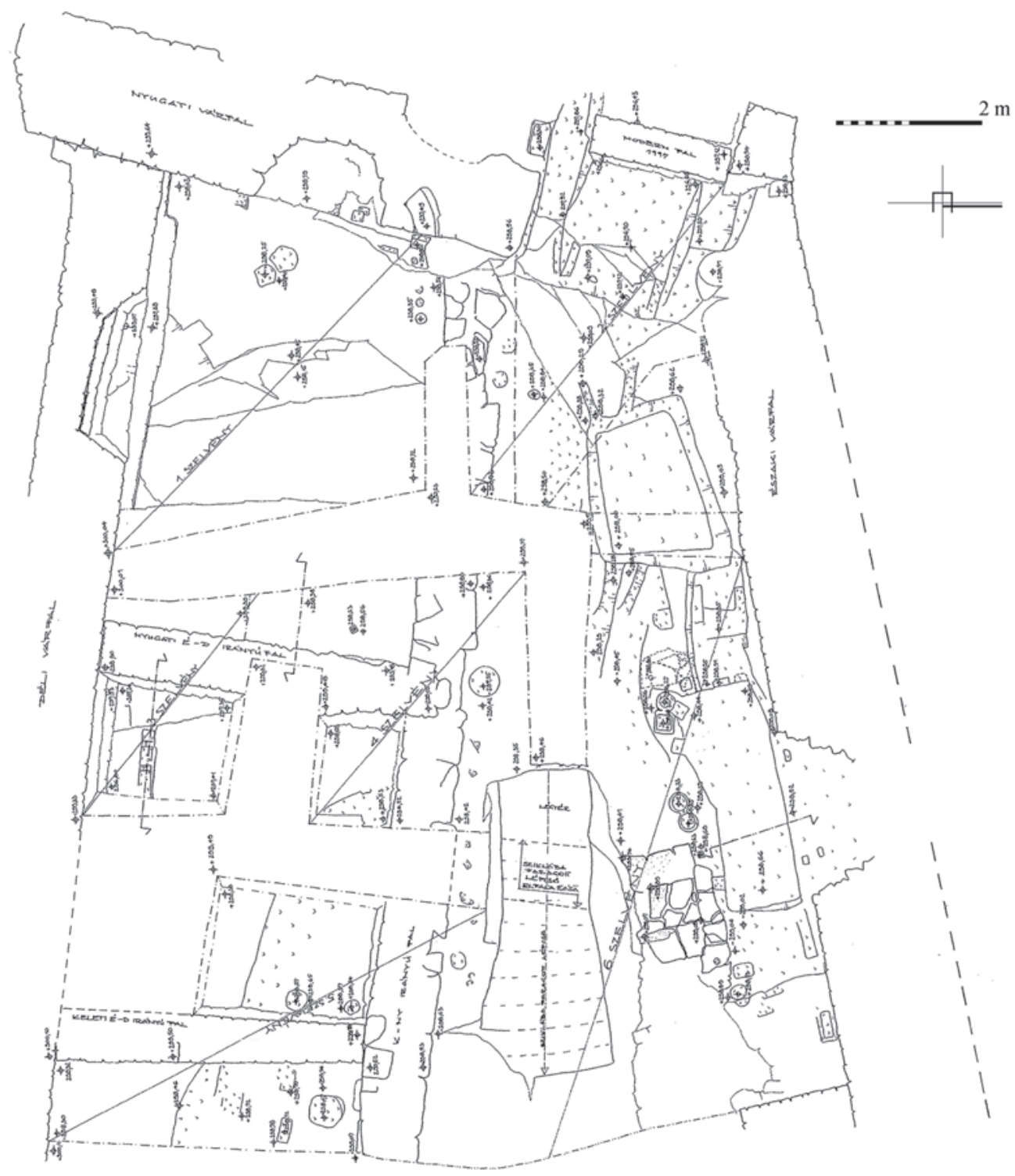

3. kép: Kutatási alaprajz a felsővár 2011. évi feltárásáról

8 A 2003-as ásatás alkalmával nem volt mód a külső falszakaszokat közelebbröl megvizsgálni.

9 Fülöp 2004. 144. 


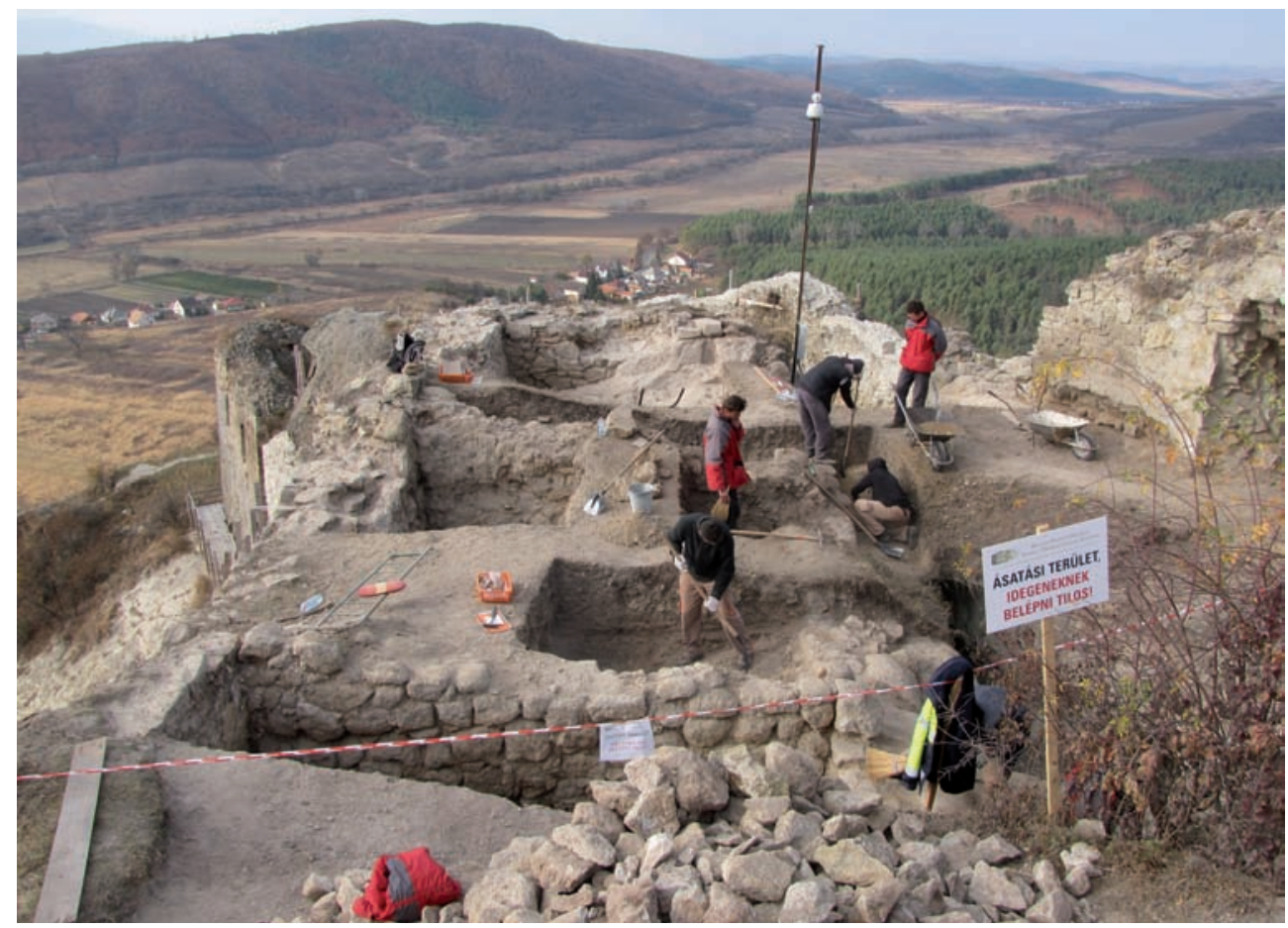

4. kép: Az ásatási terület délkelet felöl

A felsővár most feltárt részének legkorábban létrejött eleme maga a sziklalépcső (5. kép). Ennek a korai vármaggal való egykorúságára utal, hogy a várfal előterében elhelyezkedő, feltehetően természetes állapotában levő plató megközelítése más módon nehezen elképzelhető. Korhatározó leletek híján csak logikai érvek szólnak amellett, hogy a sziklalépcsőnek a későbbi alsóvár területén nyíló bejárata védelmére már az első periódusban is felhasználhatták a gyalogkapu - későbbi átalakítások során jórészt elfaragott - sziklatömbjét.

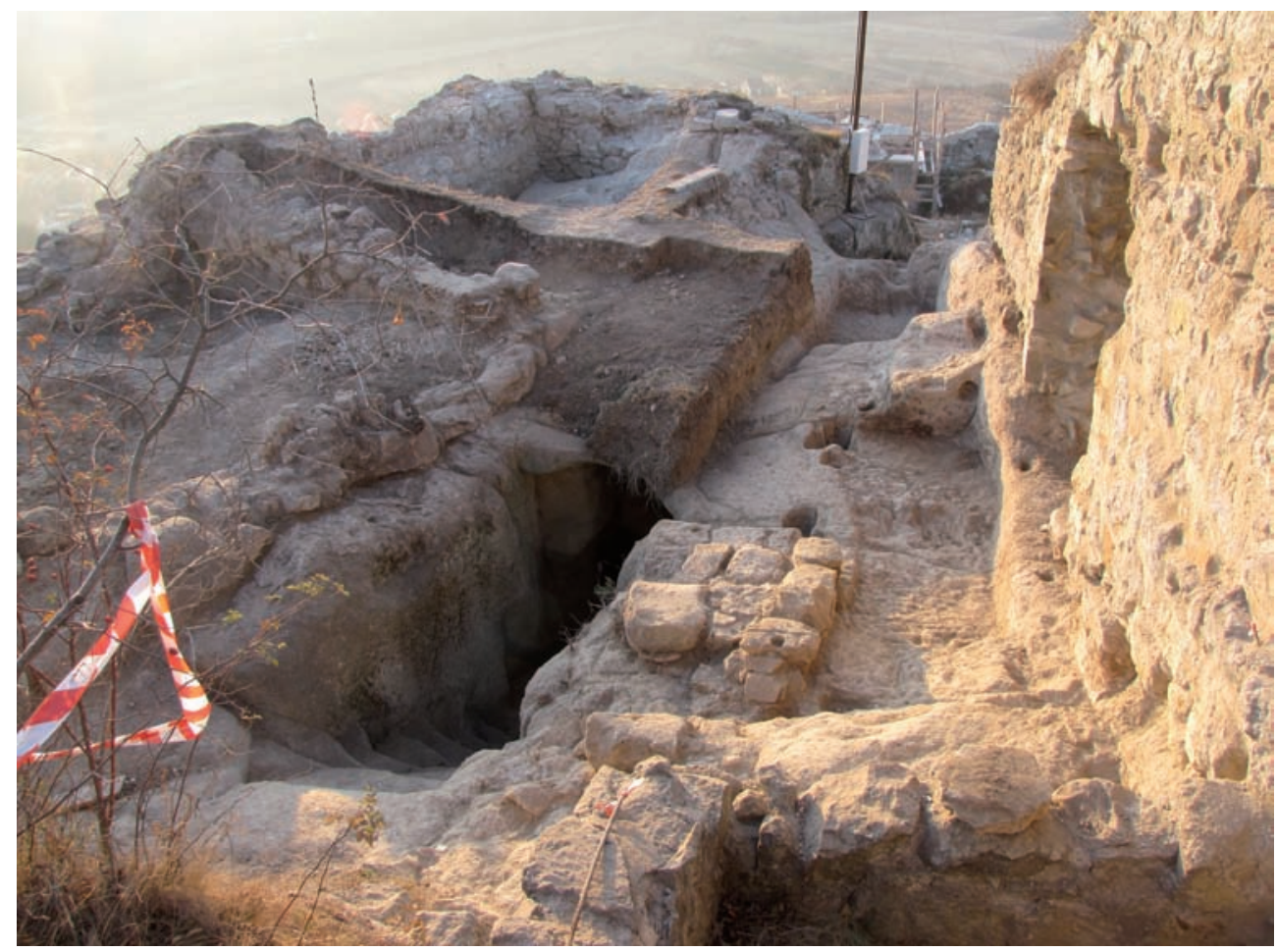

5. kép: Az ásatási terület északkelet felöl 
Az ásatás során egyértelműen ehhez a periódushoz köthető objektumokat nem azonosítottunk, így nem tudjuk, hogy a lépcső - csapadékvíz elleni, vagy hadászati célú - védelmét miképp oldották meg. Feltételezzük, hogy ekkor nyílása szűkebb volt, jelenlegi hosszúkás téglány alaprajzát csak a későbbi átalakítások során nyerte el.

A korai vármag nyugati falához a második periódusban épültek hozzá a feltárt területet délről, nyugatról és északról határoló várfalak (3. kép).

A déli és nyugati falak csatlakozásánál a várfal külső síkján jól megfigyelhető, hogy azok alsó szakaszukon kötésben épültek, feljebb azonban elválnak. A falkorona fennmaradt magasságában egyértelműen látszik a korábban, falsíkkal épült nyugati várfal és a hozzá utólag csatlakozó déli várfal vége. A szikla adottságait maximálisan kihasználó sajátos építési technikának köszönhetően a falak belső oldalán csak a falak alapozási padka illetve sziklafelszín feletti, elváló szakasza látszik, így az alsó kötésben épült és a felső elváló falszakaszok egymáshoz való viszonya belülről nem vizsgálható. Feltesszük, hogy első lépésben csupán alsó szakasza készült el, de az is elképzelhető, hogy csak építési fáziskülönbségről van szó.

A nyugati várfal középső szakaszát a nagy magasságban meghagyott sziklára ültették rá, ezen a részen a falazatnak csupán alsó kősora maradt meg. Ezek között egy falazókőként másodlagosan felhasznált faragott követ tártunk fel (9. kép 9.). Ahol a falazat teljesen lepusztult, a sziklán korábbi, fa szerkezetekre utaló befaragás-nyomokat figyeltünk meg.

A nyugati és északi várfalak csatlakozása az itt elhelyezkedő - a következő építési periódusban készült sziklába faragott kapuépítmény miatt nem vizsgálható. Az ép várfalsíkok meghosszabbításával azonban elméletben kiszerkeszthető az eredeti falsarok, melyet a kapu kialakításakor bonthattak el. Ezt a feltételezést alátámasztja az északi várfal hirtelen elvékonyodó, roncsolt falvége. A nyugati várfalat és a kapuépítményt összekapcsoló falszakasz szikláig lepusztult, ezért viszonyuk nem vizsgálható.

Az északi várfal középső szakaszán található kiromlás egy nyílás helye. Falazatában falazókőként másodlagosan felhasznált faragott követ figyeltünk meg (9. kép 8.). Az északi várfal alapozása maga a várfal szélességében meghagyott szikla. A fallal párhuzamosan, az alapozás felső síkjánál valamivel alacsonyabb, 80-100 centiméter széles padkát hagytak meg. Ennek egy rövidebb szakasza eredeti magasságában maradt meg, mellyel azonos magasságban van a nyílás fülkéjének szintén sziklából kialakított fenékszintje. Ebben két kisebb (8-10×10-12 centiméter), a falsík vonalába eső és egy hasonló, beljebb elhelyezkedő mélyedést faragtak, melyek lehetnek a nyílás kialakításával egykorúak, de későbbiek is (5. kép).

Az újonnan emelt falakkal övezett területen a sziklát a rajta megfigyelhető nyomok tanúsága szerint több helyen, nagyobb felületen megmunkálták. Emellett számos cölöplyukat és gerendafészket figyeltünk meg, melyek különböző időpontokban emelt faszerkezetű, ma már nem megállapítható funkciójú építményekhez tartozhattak. Ezen objektumok többsége egymástól függetlenül helyezkedik el, közöttük relatív kronológia felállítására sincs lehetőségünk. Emellett a nyomok legtöbbje igen sekély, betöltésük nem keletkezett, ezért abban korhatározó leletanyagot nem tudtunk feltárni. Mindezek alapján, a leletanyaggal keltezhető objektumok mellett azokat soroljuk ebbe az építési periódusba, melyek használata a következő építési periódusban biztosan megszűnt.

Az északi várfal mentén magasabban meghagyott sziklapadtól délre, a szikla lefaragásával alakították ki az új várudvar járószintjét. Feltehető, hogy a sziklalépcső aknájának mérete a felette elhelyezkedő szikla eltávolítása miatt nagyobbodott meg. Az ekkor keletkezett nagyobb nyílás lefedéséhez tartozhat a lépcső déli oldalán megmaradt padka, mely fa talpgerendát hordozhatott. ${ }^{10}$ Hipotetikusan e periódushoz soroljuk, és a sziklalépcsőt védő faszerkezetes építmény nyomainak tartjuk a lépcső déli oldalán elhelyezkedő cölöplyukakat. ${ }^{11}$

Az északi várfal nyílásának előterében, a sziklapadot lefaragva, a várfalhoz illeszkedő, nyújtott téglalap alaprajzú vízszintes felületet alakítottak ki. Ehhez az objektumhoz köthetők az annak déli széle mentén elhelyezkedő, négyzetes cölöplyukak is - mélységük 20-25 centiméter, átmérőjük 25-30 centiméter. Az objektum keleti részén két, várfallal párhuzamos, fekvő gerendához tartozó, ezekkel szemben nyugaton pedig a már említett, magasabban meghagyott sziklapad oldalába mélyedő gerendafészket figyeltünk meg. Mindezek - a nyílás padkájába faragott említett három kisebb cölöplyukkal együtt - egy, a nyílás elé épített, faszerkezetű védőépületként értelmezhetőek, melynek korábbi nyers sziklapadozata fölé később fa padozatot alakítottak ki. A mélyedés megszüntetésének idejét a betöltésében talált 14. századra keltezhető, csigavonallal díszített kerámia adja meg (8. kép 2.).

A terület északnyugati sarkában szabálytalan négyszög alaprajzú, lefelé szűkülő, sziklába faragott medencét tártunk fel. Ebbe kelet felől egy sekélyebb és egy mélyebb folyóka vezette a vizet, a felesleg a nyugati oldalon, hasonló folyókákban távozott. A mélyebb be- és kivezető folyókák vonala egymáshoz igazodik, de a medencéhez képest szabálytalanul helyezkednek el. A medence magasabb, északi és keleti falának felső szakasza sima, kissé kifelé dől, alsó szakasza inkább függőleges kialakítású. Utóbbin és az udvar járószintjéről induló

10 E megoldás esetén valószínüleg felnyitható faszerkezetet kell feltételeznünk.

11 A cölöplyukaknak viszont eltérő a keresztmetszeti mérete és mélysége: többségük csak mintegy 5 centiméter átmérőjū és 2-3 centiméter mély, kivéve a keleti szélsőt melynek kb. 20 centiméter az átmérője és a nyugati szélsőt, mely kb. 50 centiméter mély és 40 centiméter átmérőjü. 
déli és keleti falán durva faragásnyomok figyelhetőek meg. Úgy tűnik, hogy előbb a síkra faragott várudvaron keskeny vízelvezető csatornát alakítottak ki, és később hozták létre a víz tárolására szolgáló medencét. Funkcionálisan mindkettő a terület fallal való övezéséhez köthető: az újonnan kialakult várudvaron, és építményeinek tetőfelületén összegyűlő, nagyobb mennyiségú csapadékvizet gyüjthették benne. ${ }^{12} \mathrm{~A}$ medence betöltésének alsó részéből csigavonaldíszű, 14. századra keltezhető kerámiát tártunk fel (8. kép 1.).

A harmadik régészetileg azonosítható periódusban alapvetően megváltozott a vizsgált terület közlekedési rendszere. Az udvaron a déli fallal párhuzamos K-Ny irányú épületet emelnek, illetve legkésőbb ekkor megépült a déli várfal felső szakasza (3. kép).

Az épületnek a most kutatott területre eső része egyterủ lehetett, melybe a várudvar felöl a fal keleti szakaszán nyílhatott egy ajtó. A helyiség e periódushoz tartozó vakolatának kisebb részlete maradt meg a déli várfalon, a később épült keleti válaszfal csatlakozása mögött. A déli várfalon a fallal egykorú ablakfülkét tártunk fel, melynek fenékszintje jelöli ki nagyjából a helyiség egykori járószintjének magasságát; magát a járófelületet sehol nem találhattuk meg. A helyiség omladékrétegéből az ablaknyílás előtti szakaszon gótikus ablakosztó töredékek és boltozati bordatöredékek kerültek elő (8. kép 11-14.). Az épületrész keleti szakaszán feltárt, később ismertetendő, 17. századra keltezett járószint alatt, a várfal felső szakaszához támaszkodó rétegből I. Ferdinánd 1529. évben vert denárja került elő, ami alapján ezt az építési periódust 1529 utánra, de még a 16. századra keltezzük (7. kép 1., 3.).

Ugyanekkor, az épület előtt kialakult szűkebb udvarra vezetett az északnyugati várfalsarok megbontásával kialakított kapuépítmény (6. kép). Ennek külső megközelítését nem ismerjük, feltehetően az akkor még eredeti állapotában levő alsóvári sziklatömb felhasználásával történt. A kapuépítmény megmaradt része egy négyzetes alaprajzú, nyugat felé nyitott, valószínúleg alacsony fallal határolt akna (a jelenlegi fal az 1997. évi helyreállításkor épült). Keleti falának íves kialakítása és ennek széleibe faragott két keskenyebb vágat, valamint a déli oldalon, a várfal külső síkján belül sziklába faragott fészek (persely helye), felvonószerkezet meglétére utalnak. Az új közlekedőrendszerbe nem illeszkedő sziklalépcsőt a kapu építésekor elfalazták. A lépcső földdel feltöltött aknájára részben ráfedett a felsővárba vezető, újonnan épült lépcső. Bár a lépcső akna fölé eső része mára elpusztult, a fokokon található kopásnyomok alapján eredeti szélessége rekonstruálható.

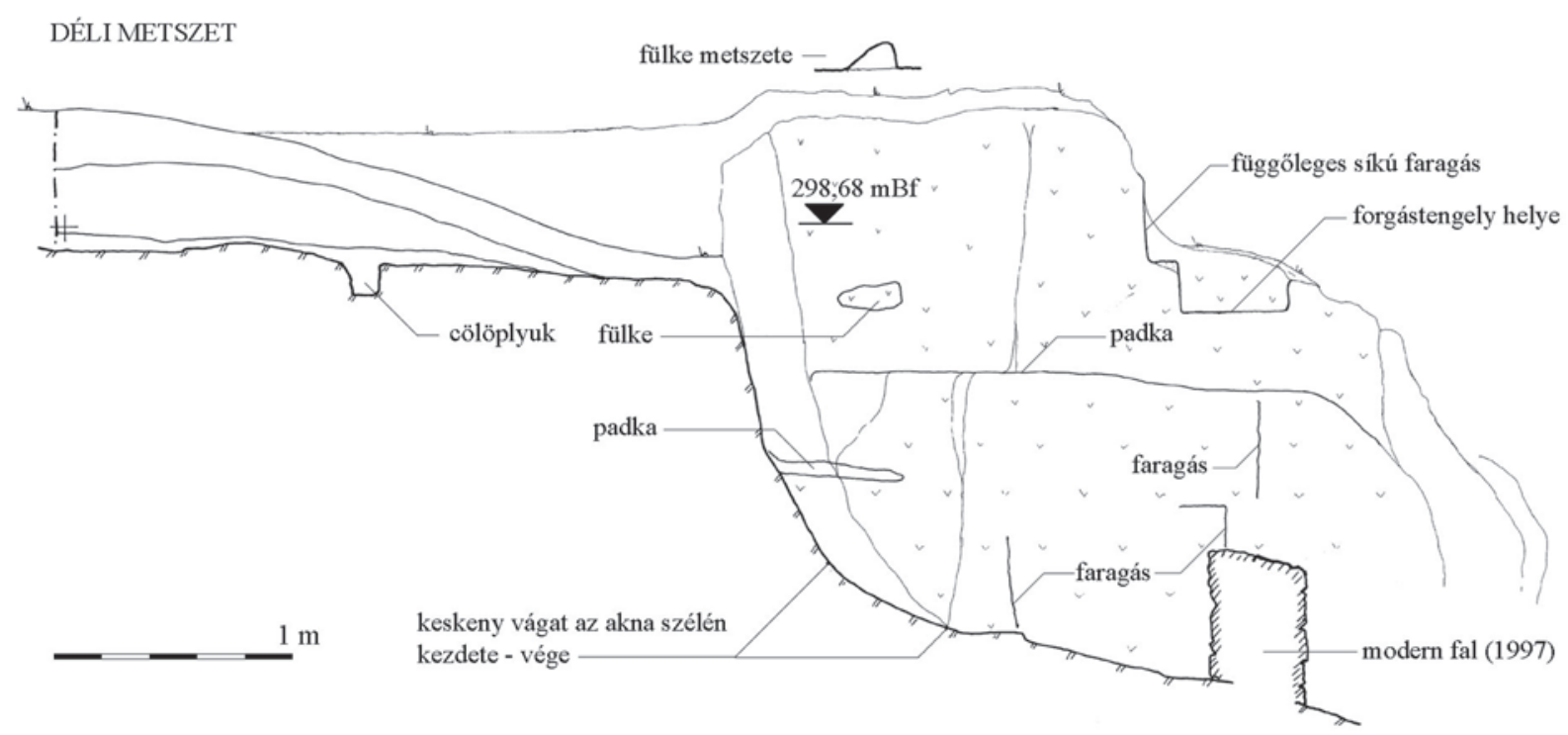

6. kép: A felsővárba vezetö, sziklába vágott kapuépítmény

A felsővár nyugati részének utolsó, negyedik periódusa idején a déli várfal melletti épületet három kisebb helyiségre osztották. Az ekkor épült falakat a korábbi járószintek elbontásával a sziklára alapozták. A helyiségeken belül minden feltárt réteg nekifutott a helyiség falainak, korábbi rétegeket vágó alapozási beásást nem figyeltünk meg. Az újonnan létrejött helyiségek közötti falakon ajtók nem nyíltak, ezért valószínű, hogy megközelítésük az udvar felöl, újonnan nyitott ajtókon keresztül volt lehetséges.

12 Lásd a szemközti asztalnál készült, jelen kötetben megjelent tanulmányt a boldogkői vár legújabb régészeti feltárásáról, Koppány András és Jankovics Norbert tollából. 

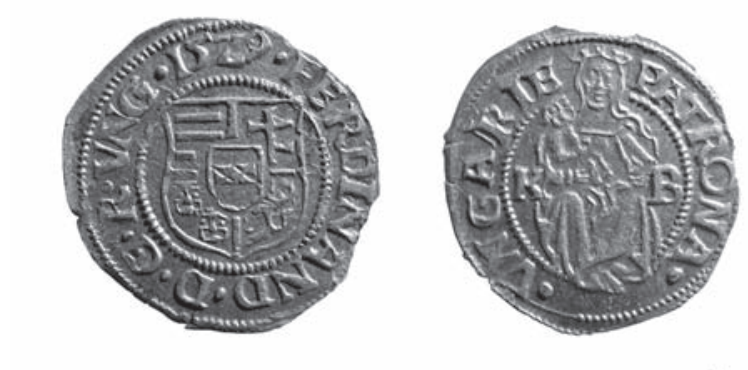

1.

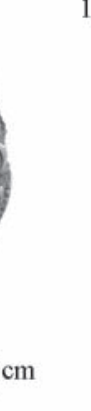

.
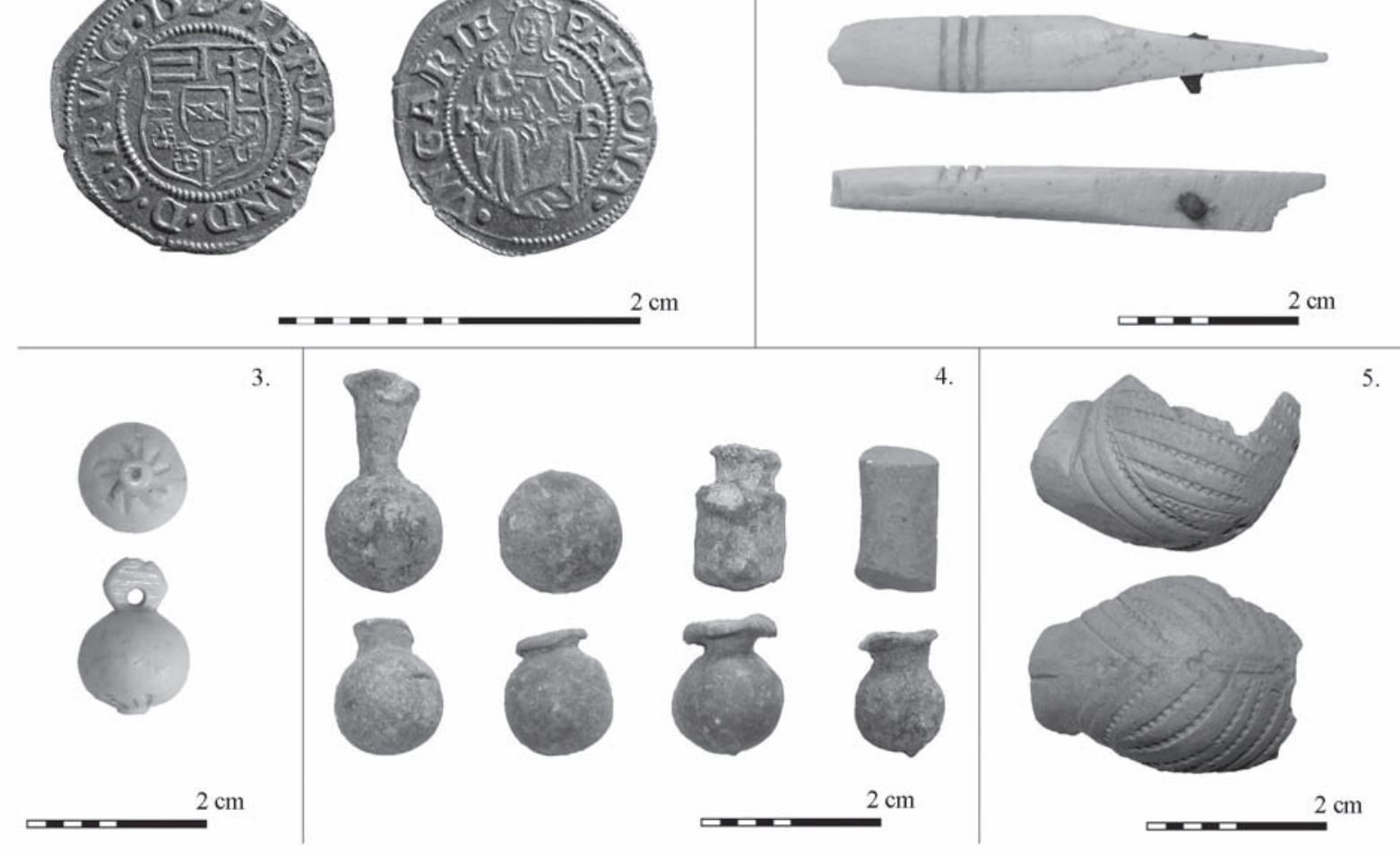

7. kép: A régészeti ásatás és szakfelügyelet során előkerült leletek

A keleti helyiségnek csak keskeny 1,20 méter széles szakasza esett az általunk feltárt területre. Udvar felóli bejárata a helyiség északnyugati sarkánál legkésőbb ebben a periódusban létrejött. A helyiség vakolatának maradványa nyugati és déli falának csatlakozásánál megmaradt. Sárga agyag járószintjéből és az afeletti kályhaomladék-rétegből zöld mázas és mázatlan török kályhaszemek (8. kép 4-5.), a járószint alatti rétegből pedig a fent említett, 1529. évben vert denár került elő (7. kép 1.).

A középső helyiség bejárata nem ismert. Sárga agyag járószintje nagyobb felületen megmaradt, alatta a helyiség északkeleti sarkában vakolattörmeléket találtunk.

A nyugati helyiség 17. századi agyagpadlója a déli várfalon az ablakfülke fenékszintje alatt 50 centiméterrel lejjebb elhelyezkedő vízkivezető nyílás szintjét tartotta meg. ${ }^{13}$ Bár a mindössze 10 centiméter átmérőjú nyílás a várfallal egyidőben kialakítottnak tűnik, rajta fúrás nyomát nem észleltük, funkcionálisan mégis e későbbi járószinthez köthető. $A$ járószint alsó rétegéből rézedénytöredék, a felső rétegből különböző típusú ólomgolyók és ólom fülesgomb, a járószint tisztításakor további ólomgolyók kerültek elő (7. kép 4.). A járószintek feletti omladékból II. Ferdinánd 1628-as veretű denárja került elő. Az ablakfülke parapetfalát keskeny eléfalazással megvastagították, eltakarva a korábbi vakolatot. A helyiségbe ajtót nyitottak az udvar felől. Ennek nyomaként magyarázható a nyugati várfalba beültetett függőleges gerendafészek, melynek kialakításakor a falban elhelyezkedő - az első periódus leírásánál említett - faragott követ is megvésték (9. kép 9.). Szintén az ajtóhoz tartozott a fal mentén elhelyezkedő három kisebb cölöplyuk, melyek küszöbgerendát, vagy lépcsőt tarthattak.

Az új helyiségek kialakításával egyidőben, az udvar teljes felületén új járószintet alakítottak ki, megszüntetve ezzel az összes, korábbi periódushoz tartozó objektumot. Egyedül a kapuépítmény és a felsővárba továbbvezető lépcső üzemelt továbbra is, utóbbi mellett keskeny, fakorláttal ellátott mellvédfalat emeltek. Ezt a legutolsó, a teljes feltárt területre kiterjedő járószintet 16-17. századi leletanyag (8. kép 4.). a felette elhelyezkedő omladékot a 17. század első felére keltezhető pénzérmék keltezik (8. kép 6.; 9. kép 10.).

Itt jegyezzük meg, a felsővárba felvezető sziklalépcső járatának keresztmetszetét legkésőbb ekkor alakíthatják át az eredeti, álló nyújtott téglány keresztmetszet oldalirányú megnövelésével. Az ebből a járatból oldalirányba vezető, már eleve íves kialakítású vágatok létesítésére az alsóvár megépítése után kerülhetett sor.

13 Ez a nyílás a déli várfal vízszintes elválásától följebb levő részében került kialakításra az építéssel egyidőben. Feltehetően egy hosszabb időre félbemaradt építkezés miatt kellett gondoskodniuk a csapadékvíz kivezetéséröl. 

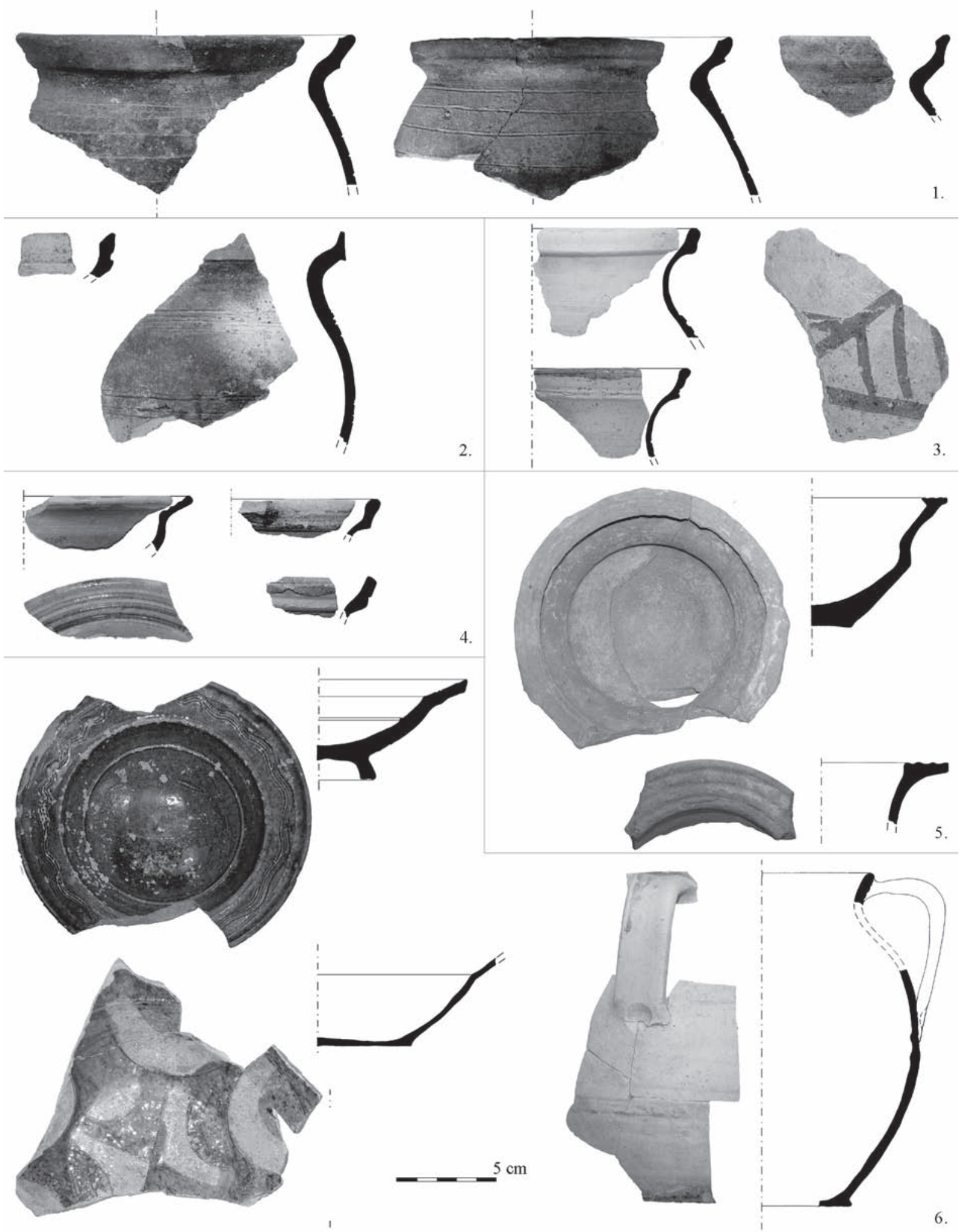

8. kép: A régészeti ásatás során elökerült kerámialeletek 


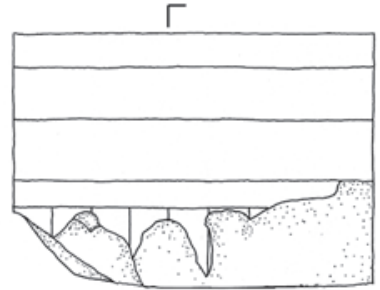

ᄂ

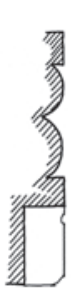

1.

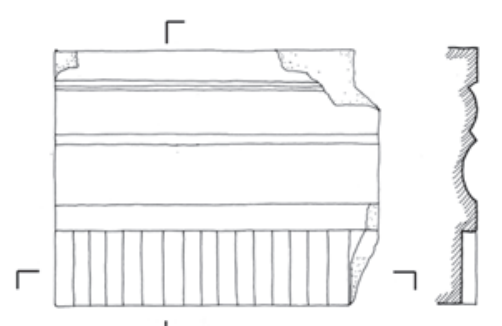

L

marmon
2.

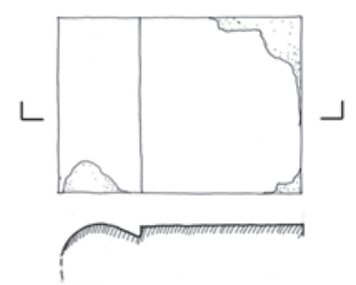

3.

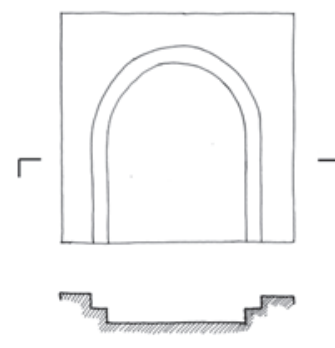

4.
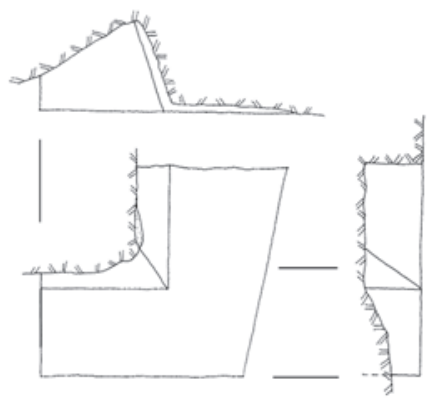

7.

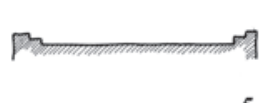

5.

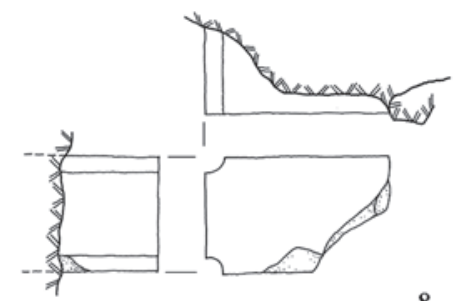

12.

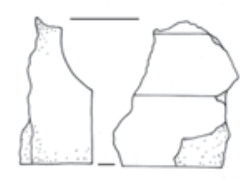

13.
8.
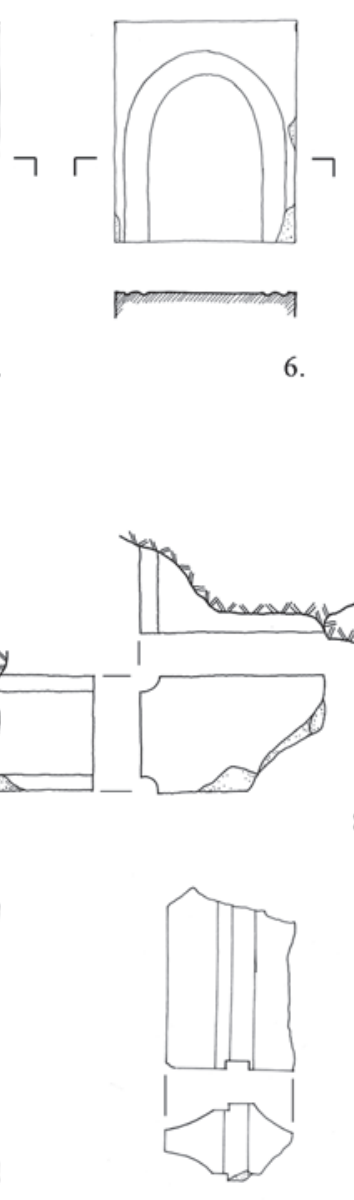

6.

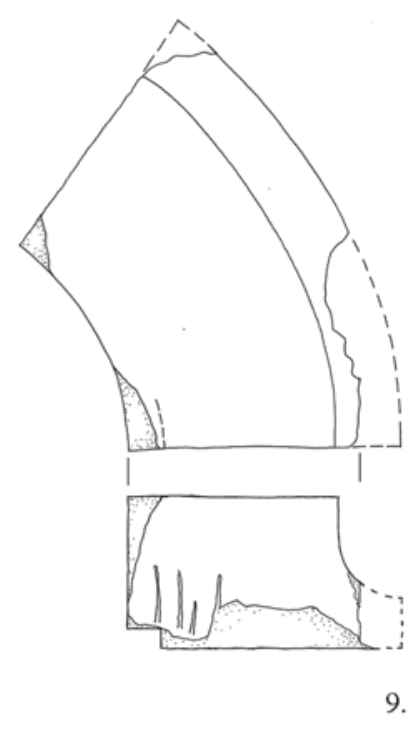

9.

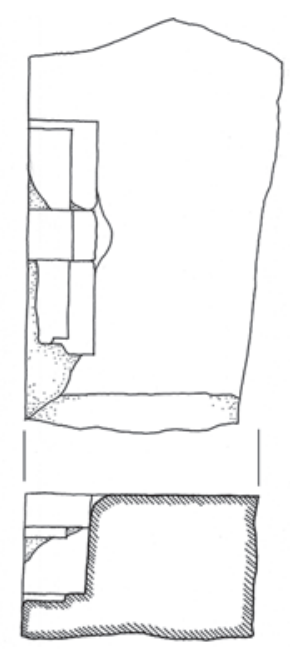

15.

9. kép: A régészeti ásatás, falkutatás és szakfelügyelet során elökerült kőfaragványok 
Mind a vár kiterjedése, mind a védelmi rendszer szempontjából jelentős lépés volt az 1562-re elkészült, bástyákkal megerősített alsóvár kiépítése (2. kép). Ennek területén az 1960-as évek ásatásai során - a már említett 1687-es inventárium felsorolásával összhangban - egy kőből épült istálló, cölöpszerkezetű épületek, gabonásvermek és kút, valamint jellemzően hódoltságkori leletanyag került elő. ${ }^{14}$

Jelen kutatás egyik feladata az ismét letisztításra került sziklafelszínek vizsgálata, és ennek részeként az ismét előkerült objektumok geodéziai felmérése volt. Ugyanakkor a kivitelezést megelőzően elvégeztük az alsóvár külső és belső falainak - szintén geodéziai felmérésre épülő - falkutatását is. ${ }^{15}$

Az alsóvárban végzett munka eredményei közül kiemelendő a déli várfal mentén állt kőistálló kutatása. Ennek déli belső falsíkján - keletről nyugat felé haladva - elsőként egy kővályú levésett, a falba in situ behelyezett darabját, felette egy szintén a fallal egykorú kiöntőnyílást azonosítottunk. A fal tövében, azzal párhuzamosan a sziklába bevágva a trágyalé összegyüjtését szolgáló vályút alakítottak ki. E vályú nem volt folytonos: nagyjából a kővályú alatt a szikla szintje rövid szakaszon padkaszerűen megemelkedett, majd ettől nyugatra ismét mélyítve, folytonosan haladt. A vájatra merőlegesen hasonló, sziklába vágott csatornát alakítottak ki, mely a várudvar vizét vezette be az istállóba, majd a déli várfalon, a kettő metszéspontjában kialakított kifolyónyíláson át a váron kívülre. Ennek fenékszintje a trágyalé-gyűjtő vájat fenékszintjénél magasabban, záradéka a fal alapozási padkájának szintjében helyezkedett el. A magasabb fenékszint arra utal, hogy a használatnak nem túlságosan ellenálló sziklavájatban fa bélést alakítottak ki. ${ }^{16} \mathrm{Az}$ istállót feltehetően félnyeregtető fedte, mely a helyiség két szélső harmadában nyitott fedélszékkel készült. A déli várfal középső harmadában megfigyelt három gerendafészek és az annak keleti és nyugati oldalán állt hevederívek arra utalnak, hogy középen gerendafödémes padlást alakítottak ki (10. kép).

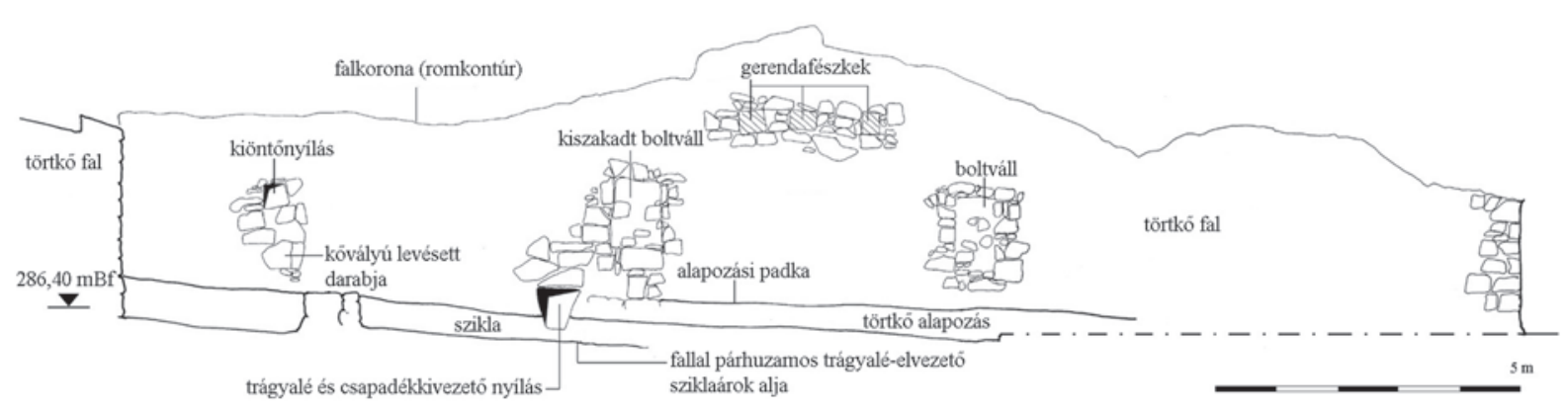

10. kép: Az alsóvári kőistálló déli falának nézete

Az alsóvár falaiban kialakított - értékelhető magasságban megmaradt - nem oldalazó helyzetben levő lőréseknél rendre megfigyelhetőek voltak a szakállas puskák rögzítéséhez szolgáló vízszintes gerendák fészkei. Az 1687-es inventárium szerint a vár tűzerejét - mint hazai várainknál általában - elsősorban a szakállasok szolgáltatták, rajtuk kívül csupán néhány tarackot írtak össze.

A vár jelen kiépítési tervének egyik sarkalatos pontja az alsóvár felvonóhidas kapujának újbóli felépítése volt. A kapu belső- és előterének feltárása már az 1960-as évek feltárása során megtörtént, felmenő falait a 2003. évi kutatás dokumentálta. A kapu előterében a feltárás óta mintegy 80 centiméter -1 méter vastag törmelék halmozódott fel. Ennek jórészt géppel történt eltávolítása után, a geodéziai felmérés során a korábban feltárt jelenségek egy részének - a belső akna és a szárazárok közötti, 2003-ban felmért falnak, illetve a szárazárok keleti oldalán 1965-66-ban megfigyelt cölöplyukaknak - pusztulását észleltük.

14 Kovács Béla ásatási jelentése 1965-66.; Kovács 1975. 250-254., Kovács 1978. 555-558. Az archív ásatási fotókon jól látszik, hogy a B-pincének nevezett, a funkcionálisan kőistállóhoz kapcsolódó sziklába vágott objektum, a ma látható formájától eltérően eredetileg felül és alul is egy-egy nyílással rendelkezett. Ez vezethette a korábbi ásatót arra a feltételezésre, hogy egy gabonásveremröl van szó, még ha ilyen típusú vermekre nemigen találunk példát, vö. Fülöp - Koppány 2006.115.

15 A falfelületekről geodéziai felmérés készült, bemérve az érdekesnek tűnő objektumok néhány jellemző pontját is. Később, a szakaszosan épülő állványzatról ezek részletes felmérése is elkészült. Mivel nem vakolt felületekről van szó, elsősorban a fugák kikaparásával lehetett az egyes, másodlagosan behelyezett köveket megmérni, illetve esetleges technológiai megfigyeléseket megtenni. A geodéziai felmérést Szökrön Péter geodéta (MNM-NÖK) készítette, akinek munkáját ezúton is megköszönjük.

16 A konferencián elhangzott elöadáshoz füzött hozzászólásában a fabélés szükségességére Mordovin Maxim hívta fel a figyelmünket. 
Az alsóvár falainak építésénél másodlagosan felhasználták egy 13. század elejére keltezhető, 1562 körül elbontott környékbeli templom ${ }^{17}$ architektúrájának faragott köveit. A töredékek között oszlopdob és háromnegyedkör metszetű falpillér rétegköve is előfordul, illetve közülük több ívsoros-fogrovatos díszű elem. Ezek a párkányelemek többféle profillal és méretben fordulnak elő, melyek kiképzése csak annyiban tér el, hogy egyazon épületről - feltehetően templomról -, de annak különböző részeiről (szentély? hajó? torony?) származhatnak (9. kép 1-7.).

Az alsóvár védelmi rendszerének teljességéhez hozzátartozik az alsóvárat északról övező, 2003-ban feltárt, belső oldalán cölöpszerkezettel megtámasztott palánk, melyre az 1687-es inventárium - a várat három részből állónak (triplex) nevezvén - is utal. Az inventárium a törökök által épített faházakról is megemlékezik, melyek azonosíthatók a korábbi ásatások során ezen a területen feltárt, várfalhoz támaszkodó kis épületekkel. A falkutatás részeként dokumentáltuk a várfalakon látható, nagyjából vízszintes bevéséseket, melyek a házak tetőszerkezetének csatlakozását jelzik. A kivitelezés közbeni megfigyelés során az alsóvár ismételten megtisztított részeiről 16-17. századra keltezhető leletanyag és egy, a vár területén eddig egyedülállóan mészkő anyagú kőfaragvány került elő (7. kép 2., 5.; 9. kép 10.).

Befejezésképp meg kell állapítanunk - örömteli -, hogy a siroki vár 1960-as évektől feltárt részeinek helyreállítása végre megtörtént, és hangot adunk annak a reményünknek, hogy ez a felsővárban most feltárt újabb falrészletek esetén is minél hamarabb megtörténik, még azelőtt hogy az építtető újabb turisztikai pályázat beadására vállalkozna.

\section{Összefoglalás}

A Heves megyei Sirok vára, melyet az Aba nemzetség tagjai építhettek a 13. század végén, elsőként 1320-ban szerepel az írott forrásokban. A 14. század folyamán királyi vár volt egészen 1389-ig, amikor a Tari család szerezte meg. 1472 után a Kompolti és a Guti Országh családok közösen bírták, amelyek közül az utóbbi egyedüli birtokosa lett 1511 után. A vár alsó része, melyet bástyákkal erődítettek, Országh Kristóf építőtevékenységének emléke 1562-ből. Noha 1596 és 1687 között a törökök tartották megszállva, a vár pusztulása nem valamely ostrom következtében, hanem a 17. század végén, 18. század elejétől, annak felhagyásával következett be.

Kovács Béla 1965 és 1972 között folytatott feltárásai eredményeképpen ismertté vált az alsóvár területe. 2003-ban Fülöp András tárta fel az alsóvártól északra lévő fa-föld szerkezetű erődítés nyomait, amelyet a 16. század végére - 17. század elejére datált. Lehetősége volt ezen kívül a felsővárban is kutatást végezni.

E cikkben a szerzők a legutóbbi ásatás eredményeit mutatják be, mely a felső vár nyugati végére terjedt ki. Egy látványos, a nyers sziklába vágott sziklalépcső vezet ide az alsóvár területéről. Négy építési periódust sikerült elkülöníteni. Az első két periódusban egy udvar helyezkedett el itt, amelynek sziklafelszínébe vágva érdekes medencéket sikerült feltárni. Ezek esővíz elvezetésére és ülepítésére szolgáltak. A harmadik periódusban egy kapuépítményt, továbbá egy új épületet emeltek ezen a területen. A leletek, különösen egy 1529-es érem alapján a szerzők még a 16. századra keltezik ezt a periódust. A negyedik építési periódusban - a 16. század végén - 17. század elején - osztófalakkal feldarabolták ezt az épületet. Mind a padlóból, mind a fölötte lévő omladékból török leletanyag került elö.

Az alsóvár turisztikai célú helyreállítása egy Európai Unió által finanszírozott projekt keretében folyt. A bástyákon és a falakon megmaradt lőrések és egyéb objektumok dokumentálása a kivitelezési munkákat közvetlenül megelőzően folyt. A falakban másodlagos helyzetű románkori faragott kövek vannak, melyek egy közeli templomhoz tartozhattak, melyet 1562 körül bontottak le.

17 A vár építőköveinek 2003-ban, Pintér Farkas által végzett anyagvizsgálata kimutatta, hogy mind az alsóvár és felsővár törtkő falazatai, mind az alsóvárban beépített kőfaragványok a környéken több helyen fejthető dácittufából készültek. Az elbontott templom párhuzamaként a közeli Váraszón álló, Erdei Ferenc tervei alapján példás módon helyreállított templomot említhetjük. A kőfaragvány csoport keltezésével legutóbb Havasi Krisztina foglalkozott doktori disszertációjában. 


\title{
Archeological investigations in the castle of Sirok (2010-2012)
}

\author{
ANDRÁS FÜLÖP - ÁGNES HÉCZEY-MARKÓ
}

Sirok castle (Heves County), which may have been built by the members of the Aba clan at the end of the 13th century is first mentioned in written sources in 1320. In the 14th century the castle remained a royal property until 1389 when it fell into the hands of the Tari family. After 1472 the castle was owned jointly by the Kompolti and the Guti Országh families, becoming the sole property of the latter family in 1511 . The lower part of the castle, which is really a fortress strengthened by bastions was built by Christopher Országh, Lord Chief Justice and governor (ispán) of Nógrád County in 1562. Although the castle was occupied by the Ottoman army between 1596 and 1687, its destruction should be dated to the end of the 17th or the beginning of the 18th century.

During the excavations led by Béla Kovács between 1965 and 1972 the entire area of the lower fortress was uncovered. In 2003 it was András Fülöp, who excavated an exterior wooden-earth fortification north of the lower fortress, which was dated to the end of the 16th or the beginning of the 17th century. He had also an opportunity to investigate the upper castle.

In this article the authors present the latest excavation, which was carried on in the western part of the upper castle. A spectacular stairway carved into the steep rock is leading from the lower fortress up to this area. Four periods were found here. In the first two periods a courtyard was situated here, where interesting basins cut into the rock were unearthed. They may have been used for leading rainwater. In the third period a new gateway and a building were erected here. According to the finds, especially to a coin minted in 1529, the authors assume, that this period goes back to the 16 th century. In the fourth period, dated to the end of the 16 th or the beginning of the 17th century, this building was divided into three rooms. From the floor and the upper rubble Ottoman finds came to light.

The lower fortress was reconstructed for tourism financed by the European Union. The remnants of the embrasures and other objects in the bastions and other walls were documented before the building works. Some architectural elements carved in Romanesque style were found in the walls. They were from a church somewhere in the neighbourhood, which was pulled down around 1562.

\section{Irodalom}

AO 1878.: Anjoukori Okmánytár. I. Szerk.: Nagy Imre - Tasnádi Nagy Gyula, Budapest

AO 1881.: Anjoukori Okmánytár. II. Szerk.: Nagy Imre - Tasnádi Nagy Gyula, Budapest

Gerő L. 1955.: Magyarországi várépítészet. Budapest

Györffy Gy. 1987.: Az Árpád-kori Magyarország történeti földrajza III. Budapest

Fülöp A. 2004.: Adatok a siroki vár építéstörténetéhez. Agria XL. 137-162.

Fülöp A. - Koppány A. 2006.: Building Technologies of Natural Rock Surfaces in Hungarian Castles (Felsenbearbeitung in ungarischen Burgen). In.: Burg und ihr Bauplatz. Castrum Bene 9., Ed.: Tomáš Durdík, Praha, 99-120.

Kovács B. 1975.: Sirok. In.: Gerő László (szerk.): Várépítészetünk. Budapest, 250-254.

Kovács B. 1978.: Sirok, vár. In.: Kovács B. (szerk.): Heves Megye Műemlékei III. Budapest, 555-558.

Vályi A. 1799.: Magyar országnak leírása III. Buda

Zichy 1871.: A zichi és vásonkeői gróf Zichy család idősb ágának okmánytára I. Szerk.: Nagy Imre, Budapest 